\title{
Zoned mantle source of Karoo flood basalts
}

\author{
A.V. LUTTINEN ${ }^{1 *}$, J.S. HEINONEN ${ }^{2}$, S.T. TURUNEN ${ }^{1}$, \\ R.W. CARLSON ${ }^{3}$, AND M.F. HORAN ${ }^{3}$ \\ ${ }^{1}$ Finnish Museum of Natural History, University of Helsinki, \\ Finland (*correspondence: arto.luttinen@helsinki.fi) \\ ${ }^{2}$ Department of Geosciences and Geography, University of \\ Helsinki, Finland \\ ${ }^{3}$ Department of Terrestrial Magnetism, Carnegie Institution \\ for Science, Washington DC, USA
}

The least-contaminated rocks of the Jurassic Karoo flood basalt province reveal considerable compositional variability in the mantle source. New and previously published $\mathrm{Sr}, \mathrm{Nd}$, and $\mathrm{Pb}$ isotopic data are suggestive of two main mantle reservoirs: one shows affinity to depleted mantle (DM) and the other has low initial $\varepsilon_{\mathrm{Nd}}(+3.3$ to 0.3$)$ and high ${ }^{87} \mathrm{Sr} /{ }^{86} \mathrm{Sr}$ ( 0.7039 to 0.7057$)$ and $\Delta 8 / 4$ (92 to 138$)$ typical of enriched mantle 1 (EM1) -affinity reservoirs. Previous studies have proposed that the DM type reservoir included domains affected by subduction-related fluids and recycled oceanic crust and that the EM1 type reservoir contained a primitive mantle (PM) type component in addition to subducted crustal material. The EM1-PM type reservoir is isotopically quite similar to the Gough component in the zoned Tristan da Cunha plume.

Importantly, the two reservoirs can be geochemically linked to a recently identified compositional asymmetry in the volumious Karoo flood basalts: The DM type reservoir is the most likely source of Nb-depleted flood basalts in the southeastern Karoo subprovince (Lebombo rifted margin and Antarctica), whereas the EM1-PM type reservoir may be the principal source of the widespread Nb-undepleted flood basalts in the Karoo-Kalahari-Zambezi basins. The boundary between the flood basalt subprovinces and the occurrences of the DM-affinity and EM1-PM-affinity rocks overlie the Jurassic location of the margin of the sub-African large low shear velocity province (LLSVP). Magmas derived from the EM1-PM type reservoir were largely emplaced above the deep mantle anomaly and we favor a plume origin for them. In contrast, magmas derived from the DM type reservoir were emplaced along the rim of the LLSVP and may represent depleted upper mantle heated by mantle plume. Speculatively, the DM type reservoir could have been a plume component and the asymmetric Karoo province as a whole may register melting of a large zoned plume source associated with the margin of the sub-African LLSVP. 